\title{
Efficiency of using high-protein soybean meal in feeding broilers of cross-breed ROSS-PM3
}

\author{
Vladimir Galkin, Natalya Vorobyova*, and Valentina Chichaeva \\ Nizhny Novgorod State Agricultural Academy, 603107 Nizhny Novgorod, Russia
}

\begin{abstract}
The use of high-protein soybean meal in broiler diets provided for 38 days of fattening obtaining live weight of $2,336 \mathrm{~g}$, average daily gain in live weight of $60.4 \mathrm{~g}$, which is higher than in the control group by $135 \mathrm{~g}$ and $3.5 \mathrm{~g}$, respectively. The highest rates were observed in chickens that consumed compound feed with high protein soybean meal, which was characterized by a high content of crude protein $(47.0 \%)$ and good protein solubility $(77.8 \%)$. It is proved that the use of soybean meal with a high content of SP - $47.0 \%$ versus $42.0 \%$, increases the live weight of chickens and reduces feed costs per 1 kilo of live weight gain.
\end{abstract}

\section{Introduction}

To actualize the genetic potential of modern broiler crosses, more and more demands are placed on the quality of the components that make up the compound feed [14]. The leading place among them is occupied by soy and sunflower meal.

The richest sources of essential amino acids, of course, are animal sources of protein. Today, the production of animal and vegetable proteins is 68 million tons per year, including 5.3 million tons of animal protein [5].

Due to the high price, components for the preparation of animal feed with animal protein are very often falsified, so in practice most diets for poultry, especially parent flocks, are composed mainly of plant sources of protein. The biological value of such diets is increased by enrichment with synthetic amino acids [6,7].

Protein of animal origin is more complete due to the wide variety and better ratio of amino acids, their greater bioavailability compared to protein of plant origin, but it is more scarce and expensive.

At present, quite a lot of research has been carried out to study the feeding of poultry by various diets in order to reduce, up to the complete exclusion, protein of animal origin and replace it with vegetable, provided that the biological value of the diets is preserved [8-10].

However, the question of optimal sources of vegetable protein in diets for broiler chickens is not well understood. Therefore, the study of this issue is relevant and important in theoretical and practical terms.

The purpose of these studies was to study the zootechnical and economic indicators of broiler chickens growing when they are fed compound feed with high protein soybean meal produced by Sodruzhestvo LLC, and its comparative assessment with a meal from another manufacturer.

The content of crude protein in the meal of LLC Sodruzhestvo was $47.0 \%$, in the meal of LLC Ussuriysk it was $42.0 \%$.

\section{Materials and methods}

The studies were carried out in 2018 in the conditions of JSC "Lindovskaya Poultry Factory - Breeding Plant" on broilers of the ROSS-PM3 cross from Day 1 to Day 38 of fattening.

The birds were kept in the same type of housing with equipment for feeding broilers in Russian-made cages 2B3 . The temperature and humidity conditions, the front of feeding, watering, and also the bird density were the same in the control and experimental groups and corresponded to the recommendations of VNITIP and manufacturers of the ROSS PM3 cross [11].

In four experimental groups there were 70347 goals, and in four control groups - 70208 heads of broiler chickens. Broilers were fed granular compound feed with nutritional value according to the norms of the crosspoultry feed manufacturer. Up to 10 days of age, broilers consumed starter feed, from 11 to 24 days - a grower, then up to 38 days - a finisher. The experimental design is presented in Table 1.

The diet composition of the experimental and control groups is presented in Table. 2 .

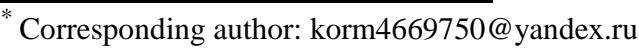


Table 1. Experiment design.

\begin{tabular}{|l|l|}
\hline Group & Feeding Features \\
\hline Control & $\begin{array}{l}\text { The main ration with the introduction of soybean meal produced by Ussuriysk LLC } \\
\text { Primorsky Krai }\end{array}$ \\
\hline Experimental & $\begin{array}{l}\text { The main ration with the introduction of soybean meal produced by LLC Sodruzhestvo } \\
\text { Kaliningrad }\end{array}$ \\
\hline
\end{tabular}

Table 2. The composition of the rations for the experimental and control groups of broilers

\begin{tabular}{|c|c|c|c|c|c|c|}
\hline \multirow{2}{*}{ The composition of the feed } & \multicolumn{3}{|l|}{$\begin{array}{l}\text { Experimental (The main ration with the } \\
\text { introduction of soybean meal produced by } \\
\text { Sodrugestvo LLC, Kaliningrad), }\end{array}$} & \multicolumn{2}{l}{$\begin{array}{c}\text { Control (the main ration with the } \\
\text { Untuction of soybean meal produced by } \\
\end{array}$} & $\begin{array}{c}|c| \\
\text { Ussuriysk LLC, Primorsky Krai), \% }\end{array}$ \\
\cline { 2 - 7 } & starter & grower & finisher & starter & grower & finisher \\
\hline Wheat & 45.11 & 65.19 & 70.40 & 45.02 & 64.08 & 70.23 \\
\hline Corn & 15.00 & - & - & 15.00 & - & - \\
\hline Soybean meal & 31.10 & 14.30 & 5.50 & 36.20 & 16.50 & 6.00 \\
\hline Sunflower meal & - & 6.00 & 8.00 & - & 6.00 & 8.00 \\
\hline Bone flour & 3.0 & 5.50 & 6.00 & 3.0 & 5.00 & 5.50 \\
\hline Sunflower oil & 2.8 & 3.60 & 3.90 & 3.3 & 2.70 & 3.70 \\
\hline Fodder yeast & - & 3.00 & 4.00 & - & 3.00 & 4.00 \\
\hline Lysine & 0.06 & 0.05 & 0.10 & 0.08 & 0.08 & 0.15 \\
\hline Methionine & 0.01 & 0.03 & - & 0.02 & 0.05 & 0.03 \\
\hline Threonine & 0.04 & 0.06 & 0.06 & 0.05 & 0.07 & 0.07 \\
\hline Monocalcium phosphate & 0.60 & - & - & 0.65 & - & - \\
\hline Defluorinated Phosphate & - & 0.29 & 0.06 & - & 0.60 & 0.06 \\
\hline Salt & 0.15 & 0.01 & 0.03 & 0.14 & 0.02 & 0.01 \\
\hline Sodium bicarbonate & 0.05 & 0.10 & 0.20 & 0.11 & 0.10 & 0.20 \\
\hline Sodium sulfate anhydrous & 0.19 & 0.2 & 0.20 & 0.15 & 0.20 & 0.20 \\
\hline Limestone flour & 0.29 & 0.15 & - & 0.30 & 0.10 & 0.20 \\
\hline Toxout+ & 0.10 & - & - & 0.10 & - & - \\
\hline Potassium carbonate & - & - & 0.05 & - & - & 0.15 \\
\hline Mineral mixture & - & 0.02 & - & - & - & - \\
\hline Premix 13455 & 1.50 & - & - & 1.50 & - & - \\
\hline Premix 09258 & - & 1.50 & - & - & 1.50 & - \\
\hline Premix 09259 & - & - & 1.50 & - & - & 1.50 \\
\hline Total & 100 & 100 & 100 & 100 & 100 & 100 \\
\hline & & & & & & \\
\hline
\end{tabular}

\section{Results}

High protein soybean meal produced by Sodruzhestvo LLC contains $47.0 \%$ crude protein, $4.1 \%$ crude fiber, $2.1 \%$ crude fat (Table 3.) No GMO was found in the meal sample. Soybean meal produced in Ussuriysk contained: $42.0 \%$ crude protein, $5.0 \%$ crude fiber, $1.9 \%$ crude fat. Feeding chickens up to 10 days of age of high protein soybean meal as part of the starter contributed to an increase in their live weight by $1.9 \%$. At 24 days and 38 days of age - by $4.8 \%$ and $6.1 \%$, respectively.

When using high-protein soybean meal in the experimental group, the average daily gain in live weight was $60.4 \mathrm{~g}$ in total, and was higher than the control by $6.1 \%$. The increased increase in live weight ensured its best conversion. For the entire period of fattening, the cost of feed per $1 \mathrm{~kg}$ of increase in live weight in the experimental groups was $1.80 \mathrm{~kg}$, and in the control - 1.87 (or which is $3.9 \%$ less than in the control).
Table 3. The chemical composition of soybean meal.

\begin{tabular}{|l|c|c|}
\hline $\begin{array}{c}\text { Chemical } \\
\text { composition of } \\
\text { soybean meal }\end{array}$ & $\begin{array}{c}\text { Experimental } \\
\text { group }\end{array}$ & $\begin{array}{c}\text { Control } \\
\text { group }\end{array}$ \\
\hline $\begin{array}{l}\text { Moisture content, } \\
\%\end{array}$ & 11.5 & 11.6 \\
\hline Crude protein, \% & 47.0 & 42.0 \\
\hline Crude fiber, \% & 4.1 & 5.0 \\
\hline Crude fat, \% & 2.1 & 1.9 \\
\hline $\begin{array}{l}\text { Soluble } \\
\text { protein, } \%\end{array}$ & 77.8 & 73.2 \\
\hline Urease & 0.08 & 0.09 \\
\hline Lysine & 2.66 & 2.42 \\
\hline Methionine & 0.57 & 0.53 \\
\hline $\begin{array}{l}\text { Methionine } \\
\text { cystine }\end{array}$ & 1.15 & 1.08 \\
\hline Threonine & 1.56 & 1.43 \\
\hline
\end{tabular}


The diets of the experimental and control groups were similar in composition, with the exception of soybean meal. Since a higher protein meal was used, this allowed to reduce the input as the meal itself - by $5.1 \%$ for the starter, by $2.2 \%$ for the grower and by $0.5 \%$ for the finisher, as well as the essential amino acids- lysine - by $33,3 \%$ for the starter, $60.0 \%$ for the grower and $50.0 \%$ for the finisher, methionine $-100,66.6 \%$ for the starter and grower, respectively, threonine $-25.05 \%$ for the starter, $16,6 \%$ - for grower and finisher. The composition of the diet for the control groups are shown in table 2 .

Table 4. Nutrition of the diet for the experimental group of broilers receiving food with soybean meal (crude protein $47.0 \%$ Sodruzhestvo LLC, \%)

\begin{tabular}{|c|c|c|c|}
\hline \multirow{2}{*}{$\begin{array}{c}\text { Feed } \\
\text { Nutrition }\end{array}$} & \multicolumn{3}{|c|}{$\begin{array}{l}\text { Types of feed in different periods of } \\
\text { fattening, } \%\end{array}$} \\
\hline & starter & grower & finisher \\
\hline $\begin{array}{c}\text { Metabolic } \\
\text { energy, kcal } \\
/ 100 \mathrm{~g}\end{array}$ & 308 & 309 & 313 \\
\hline $\begin{array}{l}\text { Crude } \\
\text { protein }\end{array}$ & 22.94 & 21.00 & 18.82 \\
\hline Crude fat & 5.07 & 6.17 & 6.51 \\
\hline Crude fiber & 3.19 & 4.17 & 4.22 \\
\hline Linoleic acid & 2.52 & 2.83 & 3.02 \\
\hline Lysine & 1.43 & 1.31 & 1.16 \\
\hline Methionine & 0.71 & 0.65 & 0.60 \\
\hline $\begin{array}{l}\text { Methionine } \\
\text { + cystine }\end{array}$ & 1.05 & 0.99 & 0.91 \\
\hline Threonine & 0.99 & 0.90 & 0.80 \\
\hline Tryptophan & 0.30 & 0.25 & 0.22 \\
\hline Arginine & 1.48 & 1.24 & 1.09 \\
\hline Calcium & 0.94 & 0.86 & 0.78 \\
\hline Phosphorus & 0.80 & 0.78 & 0.69 \\
\hline Potassium & 0.89 & 0.70 & 0.60 \\
\hline Sodium & 0.18 & 0.19 & 0.22 \\
\hline \multicolumn{4}{|c|}{ Vitamins } \\
\hline $\begin{array}{l}\text { A, thousands } \\
\text { of } \\
\text { international } \\
\text { units } \\
\end{array}$ & 15 & 13.02 & 9.38 \\
\hline $\begin{array}{l}\mathrm{D}_{3}, \\
\text { thousands of } \\
\text { international } \\
\text { units }\end{array}$ & 5.0 & 5.0 & 4.2 \\
\hline $\mathrm{E}, \mathrm{mg}$ & 100.0 & 93.38 & 56 \\
\hline $\mathrm{K}, \mathrm{mg}$ & 3.00 & 1.00 & 1.88 \\
\hline $\mathrm{B}_{1, \mathrm{mg}}$ & 3.00 & 2.01 & 1.88 \\
\hline $\mathrm{B}_{2, \mathrm{mg}}$ & 8.01 & 5.60 & 6.6 \\
\hline $\mathrm{B}_{3, \mathrm{mg}}$ & 15 & 9.34 & 9.34 \\
\hline $\mathrm{B}_{4, \mathrm{mg}}$ & 700.5 & 840 & 784 \\
\hline $\mathrm{B}_{5}, \mathrm{mg}$ & 60 & 37.38 & 37.38 \\
\hline $\mathrm{B}_{6, \mathrm{mg}}$ & 4 & 2.8 & 2.8 \\
\hline $\mathrm{B}_{12}, \mathrm{mg}$ & 0.021 & 0.014 & 0.014 \\
\hline $\mathrm{B}_{\mathrm{c}, \mathrm{mg}}$ & 1.5 & 0.94 & 0.94 \\
\hline $\mathrm{H}, \mathrm{mg}$ & 0.02 & 0.22 & 0.14 \\
\hline
\end{tabular}

A decrease in the intake of soybean meal in the diet in the control group did not adversely affect its nutritional value. Nutritional rations for the experimental and control groups are given in tables 4 and 5, respectively.

Table 5. Nutrition of the diet for the control group of broilers receiving food with soybean meal SP $42.0 \%$ USURIISK, \%

\begin{tabular}{|c|c|c|c|}
\hline \multirow{2}{*}{$\begin{array}{c}\text { Feed } \\
\text { Nutrition }\end{array}$} & \multicolumn{3}{|c|}{$\begin{array}{l}\text { Types of feed in different periods of } \\
\text { fattening, } \%\end{array}$} \\
\hline & starter & grower & finisher \\
\hline $\begin{array}{c}\text { Metabolic } \\
\text { energy, kcal } \\
/ 100 \mathrm{~g}\end{array}$ & 300 & 309 & 313 \\
\hline $\begin{array}{l}\text { Crude } \\
\text { protein }\end{array}$ & 22.88 & 21.00 & 18.87 \\
\hline Crude fat & 5.27 & 6.31 & 6.47 \\
\hline Crude fiber & 3.26 & 4.23 & 4.26 \\
\hline $\begin{array}{l}\text { Linoleic } \\
\text { acid }\end{array}$ & 2.67 & 2.94 & 3.01 \\
\hline Lysine & 1.44 & 1.32 & 1.18 \\
\hline Methionine & 0.71 & 0.66 & 0.61 \\
\hline $\begin{array}{l}\text { Methionine } \\
\text { + cystine }\end{array}$ & 1.05 & 0.99 & 0.92 \\
\hline Threonine & 0.99 & 0.90 & 0.79 \\
\hline Tryptophan & 0.29 & 0.24 & 0.20 \\
\hline Arginine & 1.45 & 1.27 & 1.08 \\
\hline Calcium & 0.97 & 0.87 & 0.73 \\
\hline Phosphorus & 0.83 & 0.78 & 0.71 \\
\hline Potassium & 0.96 & 0.70 & 0.62 \\
\hline Sodium & 0.18 & 0.19 & 0.19 \\
\hline \multicolumn{4}{|c|}{ Vitamins } \\
\hline $\begin{array}{c}\text { A, } \\
\text { thousands } \\
\text { of } \\
\text { international } \\
\text { units }\end{array}$ & 15 & 13.02 & 9.38 \\
\hline $\begin{array}{c}\mathrm{D}_{3} \\
\text { thousands } \\
\text { of } \\
\text { international } \\
\text { units }\end{array}$ & 5.0 & 5.0 & 4.2 \\
\hline $\mathrm{E}, \mathrm{mg}$ & 100.0 & 93.38 & 56 \\
\hline $\mathrm{K}, \mathrm{mg}$ & 3.00 & 1.00 & 1.88 \\
\hline $\mathrm{B}_{1, \mathrm{mg}}$ & 3.00 & 2.01 & 1.88 \\
\hline $\mathrm{B}_{2, \mathrm{mg}}$ & 8.01 & 5.60 & 6.6 \\
\hline $\mathrm{B}_{3, \mathrm{mg}}$ & 15 & 9.34 & 9.34 \\
\hline $\mathrm{B}_{4, \mathrm{mg}}$ & 700.5 & 840 & 784 \\
\hline $\mathrm{B}_{5, \mathrm{mg}}$ & 60 & 37.38 & 37.38 \\
\hline $\mathrm{B}_{6, \mathrm{mg}}$ & 4 & 2.8 & 2.8 \\
\hline $\mathrm{B}_{12, \mathrm{mg}}$ & 0.021 & 0.014 & 0.014 \\
\hline $\mathrm{B}_{\mathrm{c}, \mathrm{mg}}$ & 1.5 & 0.94 & 0.94 \\
\hline $\mathrm{H}, \mathrm{mg}$ & 0.02 & 0.22 & 0.14 \\
\hline
\end{tabular}

Table 6 presents the zootechnical indicators of broiler fattening using high protein soybean meal. 
Table 6. Zootechnical indicators.

\begin{tabular}{|c|c|c|c|c|c|c|c|c|c|c|}
\hline Indicators & \multicolumn{4}{|c|}{ Experimental group } & \multirow{3}{*}{ Mean } & \multicolumn{4}{|c|}{ Control group } & \multirow{3}{*}{ Mean } \\
\hline Group & 1 & 2 & 3 & 4 & & 5 & 6 & 7 & 8 & \\
\hline Type of housing & $\begin{array}{l}\text { chicken } \\
\text { cages }\end{array}$ & $\begin{array}{l}\text { chicken } \\
\text { cages }\end{array}$ & $\begin{array}{l}\text { chicken } \\
\text { cages }\end{array}$ & $\begin{array}{l}\text { chicken } \\
\text { cages }\end{array}$ & & $\begin{array}{l}\text { chicken } \\
\text { cages }\end{array}$ & $\begin{array}{l}\text { chicken } \\
\text { cages }\end{array}$ & $\begin{array}{l}\text { chicken } \\
\text { cages }\end{array}$ & $\begin{array}{c}\text { chicken } \\
\text { cages }\end{array}$ & \\
\hline Fattening, head & 15999 & 15972 & 19202 & 19174 & 17586 & 15239 & 20042 & 15443 & 19484 & 17552 \\
\hline $\begin{array}{c}\text { Density of landing } \\
\text { head / m2 }\end{array}$ & 35.6 & 35.5 & 35.8 & 35.7 & 35.6 & 35.6 & 35.9 & 35.6 & 35.8 & 35.7 \\
\hline Case, $\%$ & 1.90 & 1.70 & 1.60 & 1.80 & 1.75 & 1.70 & 2.30 & 1.50 & 2.20 & 1.93 \\
\hline Culling\% & 2.13 & 1.79 & 0.90 & 1.03 & 1.46 & 2.94 & 1.95 & 1.92 & 2.49 & 2.33 \\
\hline $\begin{array}{l}\text { Feeding period, } \\
\text { days }\end{array}$ & 38 & 38 & 38 & 38 & 38 & 38 & 38 & 38 & 38 & 38 \\
\hline Net gain, kg & 35463 & 34417 & 43275 & 41834 & 154989 & 30492 & 41339 & 31683 & 57988 & 161502 \\
\hline $\begin{array}{l}\text { Live weight of } 1 \\
\text { head of the main } \\
\text { slaughter, g. }\end{array}$ & 2345 & 2262 & 2404 & 2334 & 2336 & 2162 & 2213 & 2198 & 2231 & 2201 \\
\hline $\begin{array}{l}\text { The average daily } \\
\text { increase in the main } \\
\text { slaughter, g }\end{array}$ & 60.7 & 58.5 & 62.2 & 60.4 & 60.4 & 55.8 & 57.2 & 56.8 & 57.7 & 56.9 \\
\hline $\begin{array}{c}\text { Feed consumption } \\
\text { per batch, kg }\end{array}$ & 64420 & 62860 & 76100 & 74460 & 277840 & 57000 & 78386 & 57780 & 76370 & 269536 \\
\hline $\begin{array}{c}\text { The cost of all feed, } \\
\text { rub }\end{array}$ & 921653 & 903749 & 1082760 & 1074354 & 3982517 & 820530 & 1125021 & 829508 & 1096351 & 3871411 \\
\hline Conversion & 1.82 & 1.83 & 1.76 & 1.78 & 1.80 & 1.87 & 1.90 & 1.82 & 1.88 & 1.87 \\
\hline $\begin{array}{c}\text { Feed price, } \\
\text { excluding VAT rub } \\
/ . \mathrm{kg} \\
\end{array}$ & 14.31 & 14.38 & 14.23 & 14.43 & 14.34 & 14.40 & 14.35 & 14.36 & 14.36 & 14.36 \\
\hline $\begin{array}{c}\text { The cost of feed per } \\
1 \text { kg of growth, } \\
\text { rubles. without } \\
\text { VAT }\end{array}$ & 26.04 & 26.31 & 25.04 & 25.68 & 25.77 & 26.92 & 27.27 & 26.13 & 26.99 & 26.83 \\
\hline
\end{tabular}

\section{Conclusion}

Thus, the introduction into the broiler diets of high protein soybean meal produced by Sodruzhestvo LLC at all stages of feeding increases the productivity of the livestock, improves feed conversion and the use of nutrients. So, the live weight of broilers upon completion of fattening in the experimental group was higher than the control by an average of $135 \mathrm{~g}$, while reducing feed costs by $70 \mathrm{~g}$ per 1 $\mathrm{kg}$ of gain in live weight. In addition, the introduction of this meal in broiler diets at different stages of fattening can reduce the input of synthetic amino acids into the diets.

\section{References}

1. J.C. McKay, The genetics of modern commercial poultry, in: Proc. of the 23rd World's Poultry Congress (Brisbane, Australia, July 2008) CD-ROM

2. N.V. Vorobyova, V.N. Chichaeva, V.A. Galkin, The use of "Lysofort dry" when feeding broilers, Zootechnics, 11, 23-25 (2018)
3. V.A. Galkin, N.V. Vorobyeva, Influence of the drug "Lysofort" on the growth and meat productivity of broiler chickens, Zootechnics, 11, 15-17 (2018)

4. I. Egorov, T. Egorova, R. Roshchupkin, S. Kudikov, High-protein soybean meal in feed for broiler chickens, Fodder feed, 7-8, 46-48 (2017)

5. T.V. Konobley, The influence of different conditions of protein nutrition of broiler chickens on meat productivity and economic indicators, Bull. of the Lower Volga Agro-University Complex (Zootechnics and veterinary medicine), 3(31), 1-3 (2013)

6. E. Clarke, J. Wiseman, Developments in plant breeding for improved nutritional quality of soya beans II. Anti-nutritional factors, The J. of Agricultural Science, 134(2), 125-136 (2000)

7. V.I. Fisinin, The development of broiler poultry in Russia, Economics of agricultural enterprises, 1, 1416 (2005)

8. Y.H. Park, H.K. Kim, H.S. Kim, H.S. Lee, I.S. Shin, K.Y. Whang, Effects of Three Different Soybean Meal Sources on Layer and Broiler Performance, 
Asian-Australasian J. of Animal Sciences, 15(2), 254-265 (2002)

9. V. Rada, M. Lichovnikova, I. Safarik, The effect of soybean meal replacement with raw full-fat soybean in diets for broiler chickens, J. of Applied Animal Research, 45, 112-117 (2017)
10. V. Meremikwu, H. Ibekwe, A. Essein, Improving broiler performance in the tropics using quantitative nutrition, World's Poultry Science J., 69(3), 633-638 (2013)

11. V. Fisinin, I. Egorov, T. Egorova, Methodological guidelines for feeding poultry (2015) 198 p. 